\title{
Financial Difficulty of Banking Management During COVID 19 in Bangladesh
}

\author{
Md. Saiful Bari \\ Department of Brac Business School, Brac University, Bangladesh \\ E-mail: md.saiful.bari@g.bracu.ac.bd
}

\begin{abstract}
Findings point out that the savings rating operations and performances of private business Banks have outperformed these of state-owned industrial banks. The mortgage disbursement techniques of state-owned industrial banks have been now no longer efficient ample to reap required recuperation target. Furthermore, it has additionally been found that the state-owned business banks are increased in all likelihood to be affected via using each and every of the contributory factors a long way larger adversely than non-public business banks. Effective use of company governance, maintaining transparency and accountability in all respect, environment friendly financial savings risk management, bettering managerial efficiency, profitable privatization, lessening political interference and adapting contemporary technological changes, would possibly also enhance the wellknown personal loan trouble scenario of state-owned industrial banking region of Bangladesh. Countries throughout the worldwide are going through a risk of an outright disintegration as international supply chain is almost dismantled. Labor mobility too is impeded as human beings are locked down at their homes. Business enterprises, small and large, are each shutdown or closed for an indefinite period. Uncertainties are mounting as households and businesses are dealing with liquidity crisis. The key elements that have been enduring the credit score hassle (i.e. non-performing loans) had been reviewed rigorously. Contributory factors such as: corporate governance, savings management, financial savings regulations, and the degree of political interference had been identified. The first-rate direction of action is that Bangladesh Bank orchestrates a good-sized economic growth focused on repo price of four percentages and lending charge in the range of 5-8 percent.
\end{abstract}

Key words COVID19, Private bank, Retained on investment, Knowledge Management, Bangladesh Bank, Money and Liquidity.

\section{Introduction}

Ethiopia has recorded strong economic performance over the previous years, as reflected by way of the average actual GDP increase rate of about $10 \%$ per annum. The boom was expected to sustain at least for the brief term, provided that the favorable conditions continue to aid it. Over reliance on banks to enforce the stimulus package may show inappropriate Government has sought help of the banking channel to implement the stimulus package. The money from the stimulus package will be dispensed through the banking channel; whilst each credit score and series danger lie with the banks. Our banks are already overburdened with non-performing loans and poor collections. Banks need mitigate savings chance earlier than disbursing any sparkling aids which would help them to address the escalating NPL. Interest subsidy to help borrowers, situation stays over recurring non-payment - The government has determined to grant the activity amounting to BDT 2,000 crores to the banks as a subsidy and it is estimated to benefit nearly 13.8 million loan recipients. But it is also in all likelihood that the recurring nonpayer would in all likelihood fetch benefit from this stimulus package deal which would make the present-day package inexpedient.

COVID-19 influence on Insurance Sector Insurance which plays a fundamental position in 
managing risks each in micro and macro level has considered lowest penetrations in Bangladesh in contrast to its regional peers. Surprisingly, Insurance penetration has been declining for the previous various years even although the country's Per-capita GDP has been showing a stable growth over a decade now. Insurance penetration in Bangladesh stood at $0.57 \%$ in 2018 , down from $1.13 \%$ in 2010 . COVID-19 is impacting the insurance plan enterprise in multiple ways-from employee and business continuity issues to customer carrier concerns and outlook. Major segments of premium profits are anticipated to face a downward plunge. Fire Insurance- The largest source of top class for non-life insurance plan employer is fireplace insurance, which accounts for $43.1 \%$ of total top rate income for nonlife insurance companies. Factories for the RMG sector are the most important driver of furnace insurance premium. A complete of RMG factories-348 registered with BGMEA and seventy-one with BKMEA. According to BGMEA, some 268 factories out of 348 were closed temporarily, and the rest eighty have been closed permanently. A current learn about via Human Rights Watch indicates that when orders have been cancelled, $72.1 \%$ of consumers refused to pay for raw substances already purchased through the supplier, and $91.3 \%$ of customers refused to pay for the "cut-make-trim" fee - or manufacturing price - of the supplier. As a result, 58\% of factories surveyed reported having to shut down most or all their operations. This shut down of factories can also strangle the fire top class increase rate. Due to COVID-19, furnace and marine insurance are expected to take the largest hit. These two components consist of round $77 \%$ of non-life insurance businesses whole top rate income. Marine Insurance- Marine insurance plan that depends on import cargo accounts for $34.3 \%$ of the general insurance's whole top class a year. In the monetary of 2018 marine insurance plan fetched BDT 6,937.30 MN premium income. Insurance companies' top rate income from marine insurance plan is anticipated to go down to a new low if this global pandemic countries and world alternate continues to sluggish down. Bangladesh import plummeted to deepen financial disaster amid COVID-19 pandemics. Businesses did not open LCs for products, inclusive of uncooked materials of Bangladesh's greatest exporting area readymade garments, capital machinery, and intermediate goods. Plummeting import potential decrease marine insurance top rate for non-life insurance companies.

\section{Literature Review}

This ought to have negative affect for life insurance companies. Investment Income: Most of the time insurance company's top-class income is eaten away by way of claim and administration expenses. History suggests most of the insurance corporations have a combine ratio (Direct Management expenses + Claims and Commission to internet premium) above $80 \%$. As a result, they depend on investment profits for different expenses like provision, tax, and oblique management expenses. FDR consist $33.6 \%$ of total funding and capital market funding consist $28.6 \%$ of total investment. Current 5-6\% FDR rate and bearish capital market is anticipated to lower investment income in 2020. (BDT ban) Impact on Cost Centers: In 2019, non-life insurers in Bangladesh agreed no longer to provide greater than $15 \%$ commission to agents. Since these field sellers are poorly paid, they now have much less motivation to go out in the field and convey new business amid COVID-19 outbreak. So, it's anticipated that agent commission expenses can also go down. Some insurance organizations might also go for income cut throughout this COVID-19 pandemic which may want to result in lower indirect management expenses. Face-to-face sales are considered the distinctiveness of insurance plan retailers in view that coverage terms and stipulations are more difficult to be explained over the smartphone or even online. Due to halted monetary activities it will be 
tough for the field agents to convey new business. Forced repatriation of migrant workersMandatory Insurance for migrants used to be supposed to be a catalyst which will increase the top rate profits for life-insurance companies. Bangladesh confronted a double problem due to shrinking world labor market amid the COVID-19 pandemic, posing a threat to foreign remittances and at the identical time overcrowding the nearby labor market. Low margin of solvency- The insurance plan region of Bangladesh is no longer geared up to pay compensation for the medical costs and demise of the patient contaminated with corona virus due to lack of assets and funded assets. It is realized that there are no hints in the conventional insurance policies as the corona virus is new. Government Stimulus for the Textile Industry- A host of economic stimulus committed to the export-oriented industries which generally consists of the fabric industry.

A stimulus package deal of BDT 50bn for the motive of charge of salaries of employees engaged in export-oriented industries. This stimulus will be accessible in the form of mortgage at $0 \%$ interest and $2.0 \%$ one-time carrier cost for a 2 -year length with 6 months' grace

period. Bangladesh Bank's EDF has been increased by UDS 1.5bn (BDT 127.5bn) to facilitate import of raw materials below back to back LC. Under the revised rated, exporters can avail funds from EDF at $2.0 \%$ hobby rather of six-month LIBOR plus $1.5 \%$, which equates to almost $3.0 \%$ interest rate. $\mathrm{BB}$ has additionally more advantageous the mortgage ceiling for exporters from USD $25 \mathrm{mn}$ to USD $30 \mathrm{mn}$.

A new credit score facility of BDT 50bn as 'Pre-shipment Credit Refinance Scheme' has been brought by $\mathrm{BB}$ the place exporters can avail cash at $6 \%$ interest for a 3 -year duration on a revolving basis. The above insurance policies are supposed to supply a transient alleviation to the enterprise in the structure of providing cheap financing to ride out the pandemic disruptions. However, if the disaster on the demand aspect and international exchange disruption to persist past 2020, the stimulus packages would now not be sufficient to support the industry. Way Forward into the Post COVID-19 World Bangladesh textile industry is in all likelihood to go thru a wide variety of sport changing dynamics in its major export destinations, competitive strengths and furnish chain model; which can also end result in new opportunities or everlasting loss of aggressive gain of the industry if now not addressed prudently. Deteriorating change relation between the U.S. and China has created new opportunities- Since 2018, president Donald Trump has been putting tariffs and different alternate barriers towards China with the intention of forcing it to make favorable change agreements. As a result, market share of Chinese apparel exports to the U.S. declined from $33.0 \%$ in 2018 to $18.3 \%$ in March 2020 (YTD). It need to be mentioned that lengthy before COVID-19, U.S. trend brands and retailers have begun to reduce their exposure to sourcing from China, especially for the reason that October 2019 due to worries about the US China tariff war. China's misplaced market shares have been picked up usually through different Asian suppliers, particularly Vietnam (18.9\% YTD in 2020 vs. $16.2 \%$ in 2019) and Bangladesh (9.4\% YTD in 2020 vs.7.1\% in 2019). Going ahead Bangladesh has the possibility to aggressively fill the vacuum left with the aid of China. Source: WTO Source: Eurostat Demand hunch is probable to be lower for Bangladesh relative to peers- As Bangladesh is predominantly a producer of simple low-cost apparel products, in medium time period the demand hunch for Made in Bangladesh appeals is likely to be lower. Of the complete USD $34.1 \mathrm{bn}$ apparel exports in $2019,73.0 \%$ of it came from primary products such as shirts, trousers, $t$-shirts, jackets and sweaters. In the post COVID-19 
world the demand for these products are expected to be inelastic which will deal far much less of a blow to Bangladesh relative to friends producing high cost clothing products.

It is difficult to think of a country with a worse case of financial whiplash than Bangladesh, as Covid-19 wrecks 2020. The pandemic fallout is now colliding with a weak financial system that may also be heading for even larger turbulence. Before Covid-19 arrived, Dhaka already faced problems with awful loans and a banking zone that was no longer suit for purpose. These troubles have been exacerbated via a recent cross through the central bank to cap lending costs at $9 \%$. The policy, which took impact on April 1, risks slamming a monetary zone that is already reeling from rising non-performing loans. Not being in a position to rate loans effectively will if truth be told pressure industrial banks to turn the tap off to the segments of financial system most affected by way of the crisis, exactly when liquidity is plenty wished - Beidi Gu, Rohatyn Group "The Covid-19 crisis delivered salt to the wound for the banking sector," says Beidi Gu, managing director at the Rohatyn Group. "Not being in a position to price loans effectively will in actuality pressure commercial banks to turn the faucet off to the segments of financial system - small and medium-sized agencies - most affected by using the crisis, precisely when liquidity is tons needed. "With the skinny capitalization level, the banking machine has to revert to protections towards insolvency." The pandemic, in other words, hit Bangladesh when the economy and the banking device were vulnerable. The fear is that policymakers and bankers now have scant ability to respond to the damage wrought via the Covid-19 coronavirus. "The high degree of non-performing loans in the banking quarter in Bangladesh has been an area of difficulty even earlier than the pandemic," says Naser Ezaz Bijoy, united states of America chief government of Standard Chartered Bank. The problem, he adds, is that latest coverage strikes "take away the capacity to cover the risk to the full extent. With the pandemic, the hazard profile has deteriorated across the world - and Bangladesh is no exception. The influence of the hobby charge cap is even more pronounced." Naser Ezaz Bijoy, Standard Chartered Bank That created an ill-timed double whammy. The NPL problem leaves Bangladesh poorly organized to stand up to the coronavirus fallout, while the pandemic's implications will amplify the number of bad loans. In 2019, long earlier than Covid-19 hit, NPLs surged by way of greater than $117 \%$. So-called soured loans topped $\$ 12$ billion. That is no longer a huge tally relative to developed nations, but it is undeniably harmful to a poverty-stricken, $\$ 300$ billion economic system the place banks contain extra than $80 \%$ of all financing activity. Chronic graft doesn't help. Beneath a constructive macro surface is an opaque gadget that Transparency International ranks the 14th most corrupt out of 180 nations. A new record is still to be established through September 2020. "Reforming the banking quarter is one of the pinnacle priorities for the authorities to decorate the resilience of the economy," says Anne-Marie Gulde-Wolf, the IMF's Asia-Pacific deputy director. The IMF, she says, recommends "resolute steps" to beef up banking regulation and supervision, modernize state-controlled lenders, improve corporate governance, tighten standards for restructuring or rescheduling loans and internationalize legal-system provisions for loan recovery. "Efficient economic aid allocation with a highquality banking region would assist accelerate the recovery from the Covid-19 shock," GuldeWolf says, calling it an indispensable way to "restore the robust boom momentum." This new situation will require prudent administration of deposit risks and considerable improvement of commercial enterprise operation efficiencies if the financial institutions are to maximize get right of entry to finance for already harassed corporations - Rahel Ahmed, Prime Bank Yet through warping the genuine degree of chance in Bangladesh's monetary system, the charge 
cap runs afoul of all these goals. Zahid Hussain, former World Bank economist, now concerns about a spike in poverty as garment factories go idle. Before Covid-19 hit, forcing lockdowns and cancelling orders, solely about 50 million people of the nation's a hundred and seventy million lived above the poverty line, incomes greater than $\$ 2$ a day.

\section{Research Method}

The study uses descriptive method to describe the financial difficulty of banking management during Covid 19. The data acquired from related sources and an analysis is conducted during first few months of Covid 19.

\section{Findings and Discussions}

Concentration of Economic Activities in Two Major Cities Puts Bangladesh at Higher RiskEconomic activities in Bangladesh in very centered in Two essential cities i.e. Dhaka \& Chattogram. Currently, $31.9 \%$ of the country's total city populace lives in Dhaka, the biggest city China in difference to only $3.1 \%$ of the entire town populace lives in the country's biggest town Shanghai and totally $6.0 \%$ of urban population lives in India's pleasant city. In phrases of manufacturing, $87 \%$ of the country's complete output is generated from these two cities; at the identical time as in phrases of export, the share of Dhaka and Chattogram is even higher. Such large interest in Dhaka \& Chattogram in monetary things to do specifically manufacturing and service quarter locations Bangladesh at very excessive chance if contagion can't be contained. The guardian below is showing each day distribution of cautioned validated COVID-19 cases ( $=32,120)$ per division, 14 April-01 June2020, Bangladesh. Like most of the one of a nation the outbreak of the COVID-19 pandemic is a fantastic shock to the Bangladesh economy. The state of affairs for Bangladesh is higher as the financial computer was once already in a parlous state beforehand than COVID-19 struck. With the prolonged country-wide lockdown, international financial stoop and associated disruption of demand and furnish chains, Bangladesh financial machine is maybe to face a protracted period of slowdown in activity. The magnitude of the monetary have an have an impact on will remember upon the duration and severity of the fitness catastrophe and the manner in which the situation unfolds on withdrawal of the lockdown. On April 9, the chief of International Monetary Fund, Kristalina Georgieva stated that the 12 months 2020 could see the worst global monetary fallout seeing that the Great Depression in the 1930s, with over a hundred and seventy countries likely to trip horrible per capita GDP boom due to the raging coronavirus pandemic. Source: WHO

Bangladesh is no exception and projections from IMF, World Bank and ADP have been reduced drastically after pandemic. The decline in us of an extensive and international demand for manufactured goods, in specific in the garments sector will hazard growing unemployment and deepen poverty. Bangladesh scored 38.3 out of 100 and ranked one hundred and thirtieth out 141 international locations in soundness of banks. Deposits amplify in modern years declined gradually and personal quarter credit score make bigger fell to $9.2 \%$ in January 2020. Massive personal loan rescheduling of BDT 50,000 crore underneath a controversial rescheduling grant helped banks to reduce default loan of BDT 22,000 crore in the closing three months of 2019. Net undertaking margin (NIM) diminished spherical forty groundwork factors in final three years. Profitability of the quarter declined drastically. Capping hobby charge is in all possibility to aggravate Net Interest Margin - Banks in Bangladesh are implementing a hobby rate cap, a lending cost of $9.0 \%$ for all sectors without financial savings card. Capping activity value by Bangladesh financial group put banking 
sector in any different regime of difficulty, particularly in lending SMEs/MSMEs in preCOVID 19 period. The pastime cost capping would weaken the banks thru restraining their ability to repair adequate pricing of risks amid bad lending practices and a prone lousy personal mortgage recovery framework in the country.

COVID-19 impact on Digital/Mobile monetary Service providers- In 2019 the digital/mobile financial services landscape of the People's Republic of Bangladesh evolved multifold. At the top of Gregorian calendar month 2019, the country had 971,000 MFS agents and a complete of eleven,320 agent banking retailers that serve eighty-one million registered wallets. Due to service purpose shutdowns, the group action of the business has declined by around $35 \%$. A significant range of MFS agents remained enclosed internment, whereas the remaining agents open their shops for restricted hours during a day. As a result, the whole business group action and volume have reduced significantly. The contactless mobile/online payment strategies were gaining acceptance already, however, this COVID-19 pandemic has been a boon for this business the countrywide internment has slashed the revenue but it expanded the MFS market nightlong. The financial organization enclosed MFS into emergency services throughout the internment to facilitate the payments.

Moreover, government-directed involved authorities to pay some BDT four,000 large integers among four.1 million readymade garments (RMG) employees across the country. Consequently, 1.92 million MFS accounts were opened in the mere 1st period of Apr. Alternative delivery channels saw a spike in retail demand in COVID-19 The business is expecting to launch MFS ability before long which will have a positive impact on more than eighty-one million registered wallets across sixty-four districts in the People's Republic of Bangladesh. it'll ease creating and receiving payments for merchandise and services, particularly for MSMEs and increase total transactions. Impact on e-commerce \& e-servicesAmid the COVID-19 closedown, range of on-line purchases mistreatment the B2C ecommerce platforms i.e., daraz.com, Shwapno.com, chaldal.com, etc. increased. Chaldal.com, shwapno.com, and alternative e-grocery sites have a wide increase in on-line orders once internment. Online grocery stores like Chaldea, shrapnel, etc. are experiencing growths within the number of deliveries with Chaldea's average 5000 orders-per-day jumping's to 10,000 to 15,000 orders-per-day on AN average. 'Daraz', specializing in physics, home appliances, article of clothing, etc. in the People's Republic of Bangladesh recently proclaimed in BDT 500-crore investment set up by 2021 . beneath the setup, the entity would develop its own 2,00,000- square feet warehouse and 1,50,000-square feet totally automatic sorting center.

Daraz conjointly aims to reach all sixty-four districts within the country with quite a hundred and fifty hubs by the top of this year. 'Othoba' by RFL group is another e-commerce seeing a booming increase of orders because of its Ramadan central offers and supply of PPEs and alternative hygiene merchandise, necessary merchandise throughout the COVID-19 crisis. Online purchase of medication, safety, and sanitizing kits, has inflated a great deal during this pandemic and panic buying adscititious more thereto. Pharmacy.com is that the leading online pharmacy store that has been seeing a substantial rise in sales as they're one among the few ecommerce businesses that have brought the pharmacy to a digital shopfront. Food delivery services are struggling- Food delivery services (HungryNaki, Pathao Food, Foodpanda, ShohozFood, UBEREats, etc.) have a visage severe challenges in lockdowns in Apr and will (2020) as virtually all the restaurants were closed and 30\% restaurants left the business following a loss. on-line food delivery orders fell down by seventy-five to $80 \%$. On might nineteenth the world ride-sharing platform Uber's food delivery service Uber grub set to shut 
down its operation in the People's Republic of Bangladesh from Gregorian calendar month 2020. Ridesharing still not permissible to hit the road- BRTA has prohibited the ridesharing services (UBER, Pathao, Shohoz, etc.) throughout the 2 months-long internments to limit the unfold of COVID-19. From June 2020 RMG factories, looking malls, firms have started operation at the restricted scope. Public transportation resumed on the first Gregorian calendar month however BRTA is nonetheless to allow the ridesharing services to begin operation.

Uber and Pathao, 2 high ride-sharing platforms within the country, have together requested the People's Republic of Bangladesh Road Transport Authority (BRTA) to permit ride-sharing services through apps. BRTA call during this regard might confirm the long run of those ventures in the People's Republic of Bangladesh. Logistics Startups are rolling on- Around three hundred little and medium-size provision firms are operational in Dhaka to support the booming e-commerce and commerce. Some provision services have seen a spike in demand. Pathao, e-Courier, Biddyut, Paperfly, Sturmarbeiteilung Paribahan these provision firms' visages AN unlikely surge in orders. Health/Telemedicine is a successive promising sectorthroughout the pandemic, the net tending service suppliers have visaged an unforeseen spike in commission requests, principally for doctor consultation and medicines. Praava Health has introduced a video consultation service already. Doctoral, Digital Health (formerly Telenor Health), Olwel are receiving thousands of calls a day. The unforeseen surge of demand during this sector has attracted other startups nightlong. The ride-hailing startup Pathao has launched a replacement service known as Pathao Health in collaboration with a variety of tending startups in Dhaka together with Digital tending Solutions (formerly Telenor Health), Praava Health, and Maya. Pathao and Shohoz are returning forward to produce telemedicine solutions and on-demand medication delivery. The post-COVID-19 world won't be an equivalent once more. The new tradition might come back up with a modified Lifestyle, getting behavior, means of doing business, and interfaces.

Post-pandemic solutions of distinctive problems we have a tendency to face in the COVID-19 pandemic may lay the foundation for several business ideas and may shape the way forward for our e-commerce business within the returning years. Certain banking services like repayments are considered as critical offerings in this lockdown environment, and as such bankers, at least a phase of them, are usually there in their places of work to help their clients. Thus, a right fluctuate of economic institution executives are going via higher Covid-19 illness danger like some of the frontline troopers in the corona war--- medical physicians and fitness workers, public servants, and one-of-a-kind useful resource provider carriers who are working outdoor their homes. Despite being in this integral and extraordinary environment, the banking enterprise cannot come up with the money for to break out action and education for figuring out the existing and future risks associated with the banking businesses. Otherwise, efforts of the united states of the united states would be wasted and the economic restoration will be delayed.

The banking risks can also moreover stem from one of a variety sources, and at present we have a congenial environment, even though there are all the factors that would possibly also quit result in huge risks of one of a kind sorts in banking operation. Economic and company matters to do have come to an unparalleled halt and there are massive financial and business organization uncertainties all over the globe. Domestic and global trade, transportation and communications are severely disrupted, and entrepreneurs are confronted with clear future cash-flow uncertainties and lack of confidence. All related things to do and consumers of banks are moreover now no longer superb about their future crook liabilities in the post- 
Covid-19 environment.

\section{Conclusion}

Production may get relocated to developed international locations in the long term- The world has been sourcing majority of its clothing from South Asia till now due to the region's low value of manufacturing (mainly derived from low labor cost). However, with the advent of automation and higher technological innovation, superior nations are probable to overcome the advantage of inexpensive labor of South Asian countries. With the need for boosting economic activities to come out of the COVID-19 induced recession we may additionally witness relocation of apparel services from South Asia to superior economies. Bangladesh might also lose world market share- pushed by means of faster post pandemic rebound of rival countries, particularly China and Vietnam. China being the united states of America of origin of COVID19 has the most journey in dealing with the pandemic. It has successfully applied massive scale trying out and tracing and is probably to be amongst the first nations to come out of the pandemic and open its economy in full swing. Next, Vietnam is considered to be a success story in warfare the COVID-19 pandemic with no deaths and only round 329 cases in a united state of America of ninety-seven million. It managed to do so with the aid of being among the earliest to recognize the severity of the pandemic and enforce rapid strategic testing, aggressive contact tracing and wonderful public awareness as early as January 2020. In addition, Vietnam's Free Trade Agreement with the EU is probable to come into effect in 2020 paving the way for Vietnam to penetrate EU apparel market. The industry will have to initiate big technological upgradation and discover out approaches to shorten its supply chain and that too in a span of one to two years to stay competitive in the global market. The already struggling Bangladesh Power Development Board (BPDB) will be the affected Bangladesh already has excess capacity that consequences in developing potential repayments by BPDB to plant life mendacity idle. This payment is funded via an ever-increasing subsidy from the government as the operating profits of BPDB cannot cover the cost. Overall power ability utilization in Bangladesh for 2018-19 used to be simply 43\%, while capacity payments to idle flowers reached $\sim$ BDT 89.3 bn in 2018-19. This scenario will get worse driven by lower electricity demand and increasing capacity expansion in the upcoming years.

\section{References}

Dong E, Du H, Gardner L. An interactive web-based dashboard to music COVID-19 in true time. Lancet Infect Dis. (2020). doi: 10.1016/S1473-3099(20)30120-1 Li Q, Guan X, Wu P, Wang X, Zhou L, Tong Y, et al. Early transmission dynamics in Wuhan, China, of novel coronavirus-infected pneumonia. N Engl J Med. (2020) 382:1199-207. doi: 10.1056/NEJMoa2001316

Bootsma MCJ, Ferguson NM. The impact of public health measures on the 1918 influenza pandemic in U.S. cities. Proc Natl Acad Sci USA. (2007) 104:7588-93. doi: 10.1073/pnas.0611071104

Perera W. Bangladesh Government Downplays COVID-19 Threat as Job Losses Mount. (2020). Available on line at: https://www.wsws.org/en/articles/2020/03/16/bang-m16.html (accessed March 26, 2020). Directorate General of Health Services. Novel Coronavirus (COVID-19) Press Release. (2020). Available on line at: https://www.dghs.gov.bd/index.php/en/home/5373-novel- 
coronavirus-covid-19-press-release

(accessed

April

11,

2020).

Institute of Epidemiology DC and R. COVID-19. (2020). Available on line at: https://www.iedcr.gov.bd/index.php/component/content/article/73-ncov-2019 (accessed April 11 ,

2020).

Worldometer. Covid-19 Coronavirus Pandemic. (2020). Available on line at: www.worldometers.info/coronavirus/ (accessed April 13, 2020).

Javed HAl. Passengers From Europe Land in Dhaka Despite Ban. (2020). Available on line at: https://www.dhakatribune.com/bangladesh/dhaka/2020/03/16/defying-bar-european-flightlands-in-dhaka

Molla MA-M. Govt Now Scrambles for Testing Kits, PPE. (2020). Available on line at: https://www.thedailystar.net/frontpage/news/govt-now-scrambles-testing-kits-ppe-1882633

The New Age. Six of Seven Thermal Scanners in Bangladesh Inoperative. (2020). Available on line at: https://www.newagebd.net/article/101488/six-of-seven-thermal-scanners-inbangladesh-inoperative

Sujan MA, Hasan R. Coronavirus Outbreak: Screening Still Lax at Dhaka Airport. (2020). Available on line at: https://www.thedailystar.net/frontpage/news/coronavirus-outbreakscreening-still-lax-dhaka-airport-1878607

Maswood MH, Chowdhury SI. Bangladesh Bans Travellers' Entry From Europe. (2020). Available on line at: https://www.newagebd.net/article/102202/bangladesh-bans-travellersentry-from-europe

Dhaka Tribune. Coronavirus: Overseas Returnees Roaming Around Violating Govt Directive, Hundreds Fined. (2020). Available on line at: https://www.dhakatribune.com/bangladesh/nation/2020/03/19/expats-roaming-around-inquarantine-hundreds-fined-over-a-million-taka bdnews24.com. Army to Run Coronavirus Quarantine Units in Dhaka's Ashkona, Diabari. (2020). Available on line at: https://bdnews24.com/bangladesh/2020/03/20/army-to-runcoronavirus-quarantine-units-in-dhakas-ashkona-diabari

Mahmud F. Bangladesh Founder's Birth Centenary Event Postponed. (2020). Available online at: https://www.aljazeera.com/news/2020/03/coronavirus-bangladesh-founder-birthcentenary-event-postponed-200309113459629.html

bdnews24.com. Bangladesh to Ban All Rallies After Coronavirus Advice Defied. (2020). Available on line at: https://bdnews24.com/bangladesh/2020/03/20/bangladesh-to-ban-allrallies-after-coronavirus-advice-defied

Chowdhury T. Fears Grow Over Bangladesh's COVID-19 Response. (2020). Available online at: https://www.aljazeera.com/news/2020/03/fears-grow-bangladeshs-covid-19-response200323111803294.html

Dhaka Tribune. Covid-19: Immediate Expansion of Testing Labs to Districts Needed. (2020). Available online at: https://www.dhakatribune.com/health/coronavirus/2020/04/11/covid-19immediate-expansion-of-testing-labs-to-districts-needed

Chowdhury SI. China to Give Bangladesh Testing Kits, Protective Gears. (2020). Available on line at: https://www.newagebd.net/article/102576/china-to-give-bangladesh-testing-kitsprotective-gears

The Daily Star. Coronavirus Test in 15 minutes for Tk 350. (2020). Available on line at: https://www.thedailystar.net/backpage/news/coronavirus-test-15-mins-tk-350-1882597

CBC News. Canada Refuses to Approve Rapid Coronavirus Blood Test. (2020) Available on- 
line at: https://www.cbc.ca/player/play/1722212931886 (accessed April 11, 2020).

Aljazeera. Bangladesh Releases Jailed Opposition Leader Khaleda Zia. (2020). Available on line at: https:/www.aljazeera.com/news/2020/03/bangladesh-releases-jailed-oppositionleader-khaleda-zia-200325121254384.html

bdnews24.com. Khaleda, Freed with the resource of Hasina, Goes Into Quarantine at Gulshan Home. (2020). Available on-line at: https://bdnews24.com/politics/2020/03/25/bnp-chiefkhaleda-zia-is-released-after-25-months-behind-bars

The Financial Express. RMG Workers Returning Dhaka to Save Jobs Amid Virus Fear. (2020). Available online at: https://thefinancialexpress.com.bd/national/rmg-workersreturning-dhaka-to-save-jobs-amid-virus-fear-1586003905

GardaWorld. Bangladesh: Government Extends Existing COVID-19 Restrictions Until April 25 and Imposes Curfew From April 10. (2020) Available on-line at: https://www.garda.com/crisis24/news-alerts/331331/bangladesh-government-extendsexisting-covid-19-restrictions-until-april-25-and-imposes-curfew-from-april-10-update-7 GardaWorld. Bangladesh: Government Extends Nationwide Lockdown Until April eleven (2020). Available on line at: https://www.garda.com/crisis24/news-alerts/328426/bangladeshgovernment-extends-nationwide-lockdown-until-april-11-update-5

BBC News. Coronavirus: Bangladesh Locks Down a Million in Rohingya Camps. (2020). Available on line at: https://www.bbc.com/news/world-asia-52227924

Bangladesh Bureau of Statistics. Population and Housing Census 2011 - National extent 2: Union Statistics. Dhaka (2015). Available on-line at: http://www.bbs.gov.bd/WebTestApplication/userfiles/Image/National Reports/Union $\underline{\text { Statistics.pdf }}$

\section{Copyrights}

Copyright for this article is retained by the author(s), with first publication rights granted to the journal.

This is an open-access article distributed under the terms and conditions of the Creative Commons Attribution license (http://creativecommons.org/licenses/by/4.0/) 